\title{
R. VANCE PEAVYN sosiodynaaminen ohjaus
}

\author{
"The person is not the problem, \\ the problem is the problem." \\ (R. Vance Peavy)
}

$\mathrm{O}$ hjauksen historia on osa yksilöllisyyden historiaa. Yksilön valintoja korostaessaan ohjaus on osaltaan palvellut yhteiskunnallisena kittinä ja oikeuttanut ideologiaa "jokainen on oman onnensa seppä".

Ohjausammattilaiset näkevät ohjauksen usein juuri yksilön valintojen tukijana. Yksilö- ja talousnäkökulman ristivetoisuus näkyi jo ammatinvalinnanohjauksen perustajan, amerikkalaisprofessori Frank Parsonsin (1854-1908) toiminnassa. Filantrooppina Parsons uskoi, että on mahdollista luoda yhteiskunta, jossa jokaisen kyvyt voivat kehittyä täyteen mittaansa. Ohjauksen tuli olla systemaattista ja tieteellistä. Tuon ajan voimakas maahan- ja maaltamuutto mahdollisti teollisuuden kasvavan työvoiman tarpeen tyydyttämisen, ja tehokkaan ammatinvalinnanohjauksen katsottiin palvelevan työmarkkinoita ja talouskasvua.
Carl Rogersin (1902-1987) asiakaskeskeisyys 1940-luvun lopulta lähtien liikautti painopistettä asiakkaan mittaamisesta humaanimpaan suuntaan.

\section{OHJAUS ELÄMÄNSUUNNITTELUNA}

OECD ja EU-komissio painottavat nykyisin elinaikaista ohjausta (life long guidance). Ajatusmalli pitää sisällään monia kannatettavia ajatuksia elämän ja uran siirtymävaiheiden tuesta, mutta se perustuu viime kädessä ajatukseen koulutuksesta talouskasvun moottorina ja ohjauksesta moottorin voiteluaineena (Plant 2001, 18).

Ohjaus saa oikeutustaan myös toisesta suunnasta, kun ihmisten on tavalla tai toisella voitava suunnistaa kasvavan epävarmuuden keskellä. Uudelleenarvioon ovat joutuneet niin teollisen modernin aikaiset, positivistisen psykologian sävyttämät ammatinvalinnan ja urasuuntautumisen teoriat kuin lineaaris-kausaali- 
set yhteiskuntakäsitykset. Väistyvä mutta sitkeä matsausajattelu, "oikea mies oikealle paikalle", juontui jo Platonin Valtio-teoksesta ja perustui käsitykseen niin työmarkkinoiden ja ammattien kuin yksilön muuttumattomuudesta.

Ohjaus on laajentunut useissa viime vuosikymmenten keskusteluissa ja osin käytännössäkin pelkästä opinto- tai uraohjauksesta elämänsuunnitteluksi. Vaikka monet ohjauksen työtavat painottavat yksilövalmennusta, elämänurateorioissa on viime vuosikymmeninä korostunut suhteissa olon näkökulma (Pasanen \& Vanhalakka-Ruoho 2009). Näkökulman voi nähdä jonkinlaisena kolmantena tienä, talousdeterminismin ja toisaalta abstraktien yksilövalintojen vaihtoehtona.

R. Vance Peavyn (1929-2002) mukaan työtä tai opintoja ei käsitellä irrallisina alueina, vaan niiden merkitystä kartoitetaan hyvän elämän osana. Ainoa mielekäs ura-sanan merkitys on ura elämänä tai elämä urana, jollainen on jokaisella. Ohjaus ei sulaudu terapiaan tukiessaan jaettujen kulttuuristen merkitysten ja henkilökohtaisen mielekkyyden etsimistä.

Peavy toimi kanadalaisen Victorian yliopiston professorina ja kirjoitti ohjauksesta lukuisia kirjoja ja artikkeleita. Hän koulutti ohjaajia ympäri maailmaa, myös Suomessa ja muissa Pohjoismaissa, missä hänet kotimaansa lisäksi tunnetaan parhaiten. Monissa muissa maissa Peavy lienee yhä radikaali toisinajattelija, sivussa valtavirtaohjauksesta.

\section{MITÄ ON "SOSIODYNAAMINEN"?}

Peavy nimittää kehittämänsä ohjauksen suuntausta sosiodynaamiseksi. Termin alkuosa tulee latinan sanasta socius ja viittaa itsestään selvään, mutta yksilölähtöisessä ohjauskäytännössä usein vieläkin unohtuvaan näkökulmaan, että jokapäiväinen olemassaolo on suhteissa oloa. Socius-sanan taustalla oleva kreikan aossein tarkoittaa auttamista tai toisen rinnalla olemista.

"Dynaaminen" tulee kreikan dynamikos-sanasta, joka viittaa jatkuvaan virtaukseen tai muutokseen. Se tarkoittaa myös, että jotain asiaa "luonnehtii esteettinen osien välinen tasapaino, joka tulee epävakaaksi, kun osia tarkastellaan toisistaan erillään”
(Peavy 2004). Tätä systeemistä merkitystä Peavy haluaa painottaa, koska hän väittää sosiodynaamisen ohjauksen olevan holistista toimintaa. Näin hän pyrkii ylittämään yhä sitkeän yksilö vs. yhteiskunta -dualismin sekä pääsemään eroon ihmisen redusoimisesta abstrakteihin piirteisiin tai luokitteluihin (kuten "asiakas", "uhri", "oppimisvaikeus", "tapaus", "neurootikko" jne.).

Sosiodynaaminen ohjaus on ollut osa kielellistä käännettä ohjausalalla ja samalla filosofissävyinen vastausyritys ihmisten pohdintoihin siitä, millaiset valinnat tukevat hyvää elämää. Peavy kysyy, miten voidaan välttyä siltä, että ohjauksesta tulee vain uusi tapa alistaa ja sopeuttaa ihmisiä vallitseviin kulttuurisiin uskomusjärjestelmiin. Miten vastustetaan arjen psykopatologisointia?

En väitä, että sosiodynaamisen ohjauksen ideat ja niistä johdetut ohjauskäytännöt tuottaisivat parempia tuloksia kuin muut ohjauksen tai auttamisen muodot. Sellainen väite olisi sekä mahtailevaa että ristiriidassa ohjaus- ja terapiatyön tuloksellisuutta koskevan tutkimustiedon kanssa. Yleensä ohjaus- ja terapiatyötä koskeva tutkimus osoittaa, että mikään auttamistapa ei ole selkeästi muita parempi.

Uskon, että meidät pitäisi kysyä miltä tahansa auttamismuodolta tämä kysymys: "Onko tämä viisas tapa auttaa? Onko tämä ohjausmenetelmä (tai terapiamenetelmä) kulttuurisesti järkeenkäypä? (--) Kunnioittaako se ihmisen ainutkertaisuutta ja luovuutta?" (Peavy 2004, 18.)

Konstruktionistisesti ja sosiodynaamisesti suuntautunut ohjaaja yrittää Peavyn mukaan työskennellä välittömästi asiakkaan havaintojen ja henkilökohtaisten merkitysten kanssa, jotka saadaan usein tarinan tai metaforan muodossa. Asiakkaan omasta elämästä saatava tieto on urasuunnittelun kannalta tärkeämpää kuin testitulokset. Ohjaus pyrkii reflektiivisyyden lisääntymiseen. Urasuunnittelu on vain yksi teema yksilön minäprojektissa; yksilö on kokonaisuus eikä vain urapäätösten tekijä. Tästä näkökulmasta Peavy (1996a) määrittelee uraohjauksen yleisen elämänsuunnittelun metodologiaksi. 
TARINALLISUUS JA KIELI KULTTUURISENA VÄLINEENÄ

L.S. Vygotskin jalanjäljissä Peavy (2000) painottaa kieltä kulttuurisena työkaluna. Omaksumme näitä työkaluja kasvaessamme ja opimme käyttämään niitä konstruoidessamme henkilökohtaista ja sosiaalista todellisuuttamme. Usein lainaamme siitä merkitysten ja kulttuuristen tuotosten varastosta, jonka keskellä elämme. Vuorovaikutuksessa ympäröivien maailmojen eri puolten kanssa luodaan myös uusia merkityksiä ja kulttuurisia artefakteja.

Kieli ja viestintä ovat myös ohjaajan tärkeimpiä työvälineitä, kun hän yrittää auttaa ohjattavia elämään parempaa elämää ja saavuttamaan toivottuja päämääriä. Viestintä rakentaa ohjausprosessin, ja sen avulla tehdään päätöksiä sekä luodaan ja tarkistetaan identiteettiä.

Yhteinen inhimillinen toimintatapa on se viitejärjestelmä, jonka avulla tulkitsemme vieraan kielen itsellemme. "Monikulttuurisuus" on keinotekoinen käsite, koska ohjausvuorovaikutuksessa on aina kyse kulttuurien kohtaamisesta riippumatta siitä, mistä vuorovaikutustilanteen osapuolet ovat alun perin kotoisin.

Peavy kehitteli 1980-luvulla sosiodynaamista teoriaansa samaan aikaan kun narratiivinen näkökulma lähti Australiasta ja Uudesta-Seelannista valloittamaan maailmaa. Peavy ei voinut välttyä narratiivisuuden kutsulta, vaan hän näki tarinoiden ja tarinallisen näkökulman voiman joko hyvän elämän edistäjänä tai sitä estävinä. Peavy (1991) hahmotteli erilaisia tarinamalleja tähän tapaan:

Alistamistarinat: miten olosuhteet ja toiset ihmiset hallitsevat ja painostavat

Ongelmakyllästetyt tarinat: jokin ongelma hallitsee elämää

Dominoiva tarina: jokin olennaisin seikka on koko ajan esillä

Vaihtoehtoinen tarina: miten asioiden haluaisi olevan

Toistuva tarina: jatkuvasti samanlaisena kerrottu tarina, joka estää muutoksen

Lainattu tarina: mitä muut ajattelevat tai miten muiden mielestä tulisi toimia
Protestitarina: miten vastustaa joitakin hallitsevaa voimaa elämässä jne.

Kertomuksia voi arvioida vain neuvottelemalla. Niin arkisessa kanssakäymisessä kuin ohjaustilanteessakin neuvotellaan jatkuvasti merkityksistä kielen avulla. Toiminta narratiivisena eli kertomuksellisena rakenteena on ennustamaton, mutta ei selittämätön, koska ihmiset kykenevät selittämään toimintaansa ja päämääriään. Tärkeintä ei siten ole tavoitteiden saavuttaminen, vaan se, että päämääriä muotoillaan aina uudelleen.

\section{ELÄMÄNKENTTÄ JA ÄÄNET}

Ohjausprosessin aikana työstetään yhteistyössä monia kysymyksiä, mahdollisesti esimerkiksi seuraavanlaisia: Mitä oivalluksia tai tietoja tarvitsen, jotta pääsen lähemmäs tavoitettani? Mitä taitoja minun täytyy hankkia, jotta pääsisin sellaiseen asemaan tai tilanteeseen, joka on minulle merkityksellinen? Millaiset arvot tai asenteet palvelevat minua parhaiten? Mitä mahdollisia tulevaisuuksia minulla on? Voinko nähdä itseni keskeneräisenä ja tekeillä olevana projektina? Miten voin ymmärtää paremmin ympäristöä, jossa elän, ja miten voin olla sen kanssa paremmin vuorovaikutuksessa? Mitä rajoituksia tielläni on? Voinko voittaa ne? Miten? Otanko vastuuta tekemisistäni ja ratkaisuistani? (Peavy 1997.)

Peavy tukee ohjaajien ja asiakkaiden yhteistyötä pikemminkin kulttuurisin välinein kuin psykologisin tekniikoin. Uraohjauksessa käsiteltävät kysymykset ovat harvoin irrallaan muusta elämästä, ja on varottava, että yksittäistä ongelmaa ratkaistaessa ei synnytetä lisää ja mutkikkaampia ongelmia. Kurt Lewinin elämänkentän (life space, 1948) käsitteen hyödyntäminen kertoo Peavyn pyrkimyksestä pitää menetelmä lähellä sekä käytäntöä että filosofiaa.

Elämänkentän kartoittaminen tukee holistista havainnointia. Minuuden erilaisten äänten (Mihail Bahtin) kuunteleminen tuo esiin erilaisia kertomuksia läheisyydestä ja ihmissuhteista, työstä ja koulutuksesta, terveydestä ja ruumiillisuudesta sekä henkisyydestä (spirituality). Jos ohjausvuorovaikutuksessa on löydetty uusia toiminnan mahdollisuuksia, menneisyyden, nykyisyyden ja tulevaisuudet äänet saattavat olla aiempaa toiveikkaampia. 
Keskustelin Peavyn kanssa useaan otteeseen ja osallistuin hänen koulutuksiinsa. Elämänkentän ja äänien soveltamisesta minulle on kuitenkin jäänyt parhaiten mieleen ohjaajakoulutukseen tarkoitettu video, jossa nuori naishenkilö pohtii, hankkiako lapsi vai ei.

Peavy pyysi naista aluksi visualisoimaan kartalle eli elämänkentälleen asioita ja ihmisiä, jotka tavalla tai toisella liittyvät hänen kysymykseensä. Seuraavaksi Peavy pyysi asiakastaan yhdistämään ihmisiin ja asioihin ääniä: mikä menneisyyden, nykyisyyden ja tulevaisuuden ääni sanoo hänelle mitäkin. Seuraavassa vaiheessa Peavy pyysi naista pohtimaan, mille äänelle nainen haluaisi erityisesti vastata. Case oli todellinen, ja asiakas kertoi hyötyneensä pohdinnasta, mutta tarina ei kerro, oliko ohjauksesta pitkällä aikavälillä apua. (Peavy ym. 1995b.)

\section{VIISAUS JA PAIKALLISET TEORIAT}

Ohjaus- ja neuvontatyö ei voi enää perustua paremmin tietämiseen, testaamiseen tai muuhun perinteiseen asiantuntijuuteen, vaan ohjaajan ja asiakkaan yhteistyösuhteeseen, riski- ja eettisten kysymysten ja ratkaisujen, ylipäänsä merkitysten uudelleentulkintaan yhdessä. Peavy (1996b; Spangar 2006) korostaa taitavan ohjauskäytännön rakentuvan tiedeperustaa enemmän kulttuurisesti herkkään kommunikointiin ja paikalliseen pikemmin kuin yleispätevään tietoon. Vaikka ohjauksessa ei paranneta ketään, ohjaus on lähempää sukua kansanparannukselle (healing) kuin koululääketieteelle. Ohjaustyöntekijät ja asiakkaat toimivat yhteistyössä parhaan arvauksen menetelmällä.

Sikäli kuin taitava ohjauskäytäntö rakentuu kulttuurisesti herkkään kommunikointiin ja paikalliseen tietoon, ohjausta voi kuvata 'viisaana käytäntönä'. Ennen Sokratesta kreikkalaiset pitivät viisautta ennustamiskyvyn tärkeänä osana. Platon totesi viisauden ajan olevan jo takana, ja itsensä hän määritteli vaatimattomasti uudissanalla "viisauden ystävä” eli filosofi (Colli 1997, 13-14).

Paikallinen viisaus ei ole helposti yleistettävää ja siirrettävää, vaan ainutkertaista ja tarinoihin perustuvaa. Verbit ovat substantiiveja ja abstraktioita tärkeämpiä. Viisauteen kuuluu Peavyn (2004) mukaan "joukko keskimääräistä parempia ideoita” siitä, miten elää ja miten ratkaista elämän ongelmia, muun muassa to-

\section{AINOA MIELEK ̈̈̈S}

URA-SANAN MERKITYS ON

URA EL ̈̈MÄN $\ddot{A}$ TAI

EL $\ddot{A} \ddot{A}$ URANA.

dellisuushakuisuus, pyrkimys nähdä ja havaita asiat "niin kuin ne ovat" ja antaa toisten ihmisten ja asioiden puhutella meitä ominaislaadustaan käsin.

Avoimuus kokemukselle, tieto siitä, milloin toimia ja milloin olla toimimatta sekä maailman ja ongelmien kohtaaminen rauhallisin mielin ja myötätuntoisesti kuuluvat viisauteen, samoin kyky tunnistaa, millaiset asiat etenevät yhteistyöllä. Viisauden oletetaan lisääntyvän kokemuksen myötä, mutta jos esimerkiksi ohjausammattilainen ei samalla kehity ammatillisesti, kokemus tuo vain rutiineja ja ennalta tietämistä.

Viisauteen perustuva ohjauskäytäntö on mahdollista, kun auttajat pystyvät soveltamaan eettisiä periaatteita ja toimimaan niiden mukaan niin, että heidän toiminnassaan yhdistyvät äly, tunne ja mielikuvitus. On mahdollista toimia myötätuntoisesti toisten parasta ajatellen ja samalla itseään ja omaa toimintaansa kunnioittaen. Sosiodynaamisesti suuntautuneen ohjaajan tehtävänä ei ole tehdä interventioita toisten elämään, vaan luoda oppimiselle sellaiset olosuhteet, että on mahdollista vapautua itsensä luomisen esteistä. Auttaminen ei paranna (ks. myös Onnismaa 2005), vaan se on Peavyn mukaan transformatiivinen, rakenteita muuttavan oppimisen prosessi.

Eri tavoin, muun muassa erilaisilla kysymystavoilla voidaan auttaa ohjauksessa olevaa henkilöä näkemään asioita uudella tavalla ja yhteydessä toisiinsa sekä tunnistamaan käsitystensä taustalla olevia itsestäänselvyyksiksi muuttuneita olettamuksia, joita voi käsitellä ja kyseenalaistaa ohjauksessa. Wittgensteinin $(2001,56,65)$ sanoin on "tarkasteltava läheltä", mitä tapahtuu. Peavy (1997) kuvasi mindfulnessia ohjaustaitona ja kykynä käsitellä informaa- 
tiota, nähdä vanha uudella tavalla sekä valppautena ja läsnäolona, jolla rutiinit muuttuvat luovuudeksi. Kykyä voivat kehittää niin ohjaaja kuin ohjauksen asiakaskin.

Ihmiset elävät usein maailmassa, jossa merkitykset ja monet identiteetin rakentumista tukevat instituutiot ovat tyhjentyneet. On kuitenkin mahdollista löytää uusia merkityksiä silloin kun tukena on muita, peilejä, joiden kanssa uusia tulkintoja voi tutkia ja konstruoida. Itsestäänselvyydet voidaan yhdessä asettaa kyseenalaisiksi, tehdä arki näkyväksi.

\section{PEAVYN TEOKSET}

(1991) Constructivism and the practice of storied counselling. A paper presented in the conference of IAEVG. Lisbon, Portugal, Sept 9-13.

(1995a) An orientation to constructivist career counselling. NorthStar Research Document, July.

(1995b) Vance Peavy, Gweneth Hartrick Doane \& Judy Somers. Four orientations to counselling. VHS video. University of Victoria, BC.

(1996a) Constructivist career counselling and assessment. Guidance Centre, the Ontario Institute for Studies in Education 11, 8-14.

(1996b) Counselling as a culture of healing. British Journal of Guidance and Counselling 24(1), 141-150.

(1997) SocioDynamic Counselling: A Constructivistic perspective for the practice of counselling in the 21st century. Victoria, BC: Trafford Publishing Isuom. 1999).

(2000) Ammatinvalinnan ja urasuunnittelun ohjaus postmodernina aikana. Suom. P. Auvinen. Teoksessa Onnismaa J., Pasanen H. \& Spangar T. (toim.) Ohjaus ammattina ja tieteenalana, osa I: Ohjauksen lähestymistavat ja ohjaustutkimus. Jyväskylä: PS-kustannus, 14-40.

(2004) Sosiodynaaminen näkökulma ja ohjauksen käytäntö. Suom. P. Auvinen. Teoksessa Onnismaa J., Pasanen H. \& Spangar T. (toim.) Ohjaus ammattina ja tieteenalana, osa III: Ohjauksen välineet. Jyväskylä: PS-kustannus, 16-47.
Peavy (1995a, 10) lainaa Pierre Bourdieuta (1988): "Rather than domesticating the exotic we should exoticize the domestic."

Jussi Onnismaa

Dosentti, työnohjaajakouluttaja

HY ja Kehityspiikki Consulting oy

Kiitos FT Heikki Pasaselle hyödyllisistä

kommenteista.

\section{MUUT LÄHTEET}

Bourdieu, P. (1988). Homo Academicus. Käännös: P. Collier. Stanford: Stanford University Press.

Colli, G. (1997). Filosofian synty. Suom. J. Vähämäki. Helsinki: Tutkijaliitto. (La nascita della filosofia, 1975.)

Lewin, K. (1948). Resolving social conflicts. New York: Harper \& Brothers.

Onnismaa, J. (2005). 'You can touch other people with your words': Interview with John Shotter. Lifelong Learning in Europe 10(4), 242-247.

Pasanen, H. \& Vanhalakka-Ruoho, M. (2009). Ohjaustyö ja osallisuus: Sisäistettyjä siteitä vai kasvavaa kontrollia. Teoksessa Filander K. \& Vanhalakka-Ruoho M. (toim. ). Yhteisöllisyys liikkeessä. Aikuiskasvatuksen 48. vuosikirja. Helsinki: Kansanvalistusseura, 299-324.

Plant, P. (2001). Quality in careers guidance. A paper prepared for an OECD review of policies for information, guidance and counselling services. Commissioned jointly by the European Commission and the OECD. Paris.

Spangar, T. (2006). SocioDynamic career counselling: Constructivist practice of wisdom. Teoksessa M. McMahon \& W. Patton (toim.) Career counselling: Constructivist approaches. Australia, UK: Routledge.

Wittgenstein, L. (2001). Filosofisia tutkimuksia. Suom. H. Nyman. Helsinki: WSOY. (Philosophische Untersuchungen, 1953). 